\title{
A surgically placed epidural catheter in a patient with spinal trauma
}

\author{
Douglas D. Seal MD, * \\ Rock G. Loken MD FRCPC, * \\ R. John Hurlbert MD PhD FRCSC'
}

Purpose: To report the succesful perioperative anaesthetic and analgesic management of a spinal trauma patient with a surgically placed epidural catheter.

Clinical features: A I5-yr-old adolescent woman sustained an unstable spinal column injury with an incomplete neurological deficit following a high speed motor vehicle accident. She was scheduled for spinal decompression and stabilisation through a left thoracoabdominal approach. Balanced general anaesthesia was undertaken. Prior to closure, a multi-orifice epidural catheter was surgically placed under direct vision $5 \mathrm{~cm}$ into the anterior epidural space. The catheter was then tunnelled out through the psoas muscle and secured in place. Combined epidural-general anaesthesia was then initiated for the duration of the case using $5 \mathrm{ml}$ bupivacaine $0.25 \%$ after an initial test dose of $3 \mathrm{ml}$ lidocaine $1.5 \%$ with epinephrine. An infusion of bupivacaine $0.10 \%$ and fentanyl $5 \mu \mathrm{g} \cdot \mathrm{ml}^{-1}$ at $8 \mathrm{ml}^{\prime} \mathrm{hr}^{-1}$ using patient controlled epidural analgesia (PCEA) provided excellent postoperative pain control for four days. She had an uncomplicated postoperative course.

Conclusion: A surgically placed epidural catheter provided excellent, sale, perioperative anaesthesia and analgesia in this patient with unstable spinal trauma.

Objectif : Rapporter le traitement périopératoire anesthésique et analgésique d'un trauma du rachis au moyen d'un cathéter péridural placé au moment de la chirurgie.

Aspects cliniques : Une adolescente de 15 ans, impliquée dans un accident de la route subi à haute vitesse, a présenté une fracture instable du rachis avec déficit neurologique incomplet. Elle a été opérée sous anesthésie générale pour décompression de la moëlle et stabilisation du rachis par approche thoracoabdominale gauche. Avant la fermeture, un cathéter épidural multiorifices a été placé sous vision directe par le chirurgien, $5 \mathrm{~cm}$ étant introduit dans l'espace épidural antérieur. Le cathéter a ensuite été tunellisé à travers le muscle psoas et fixé solidement en place. A partir de ce moment, une anesthésie épidurale a complété l'anesthésie générale pour le reste du cas, utilisant $5 \mathrm{ml}$ de bupivacaïne $0,25 \%$ après une dose test initiale de lidocaïne 1,5\% avec adrénaline. Une infusion de bupivacaïne $0,1 \%$ avec fentany $5 \mu \mathrm{g} \cdot \mathrm{ml}^{-1}$ à raison de $8 \mathrm{ml} \cdot \mathrm{hr}^{-1}$ selon le mode analgésie péridurale a permis un contrôle de la douleur postopératoire pour 4 jours. Le postopératoire a été sans complication.

Conclusion : Un cathéter péridural placé par le chirurgien a fourni une anesthésie et une analgésie périopératoire sécuritaire et d'excellente qualité chez cette patiente présentant un trauma instable du rachis.

From the Department of Anaesthesia* 1 and the University of Calgary Spine Program, ${ }^{\dagger}$ Foothills Hospital, University of Calgary, Calgary, Alberta T2N 2T9. 
$\mathrm{P}$ OLYTRAUMA patients with unstable spinal column injuries present many challenges for anaesthetic and perioperative care. These patients are at high risk for multisystem perioperative complications due to their injuries and immobility imposed by an unstable spine. ${ }^{1,2}$ They often require major surgical procedures for decompression and stabilisation. Ideally, such patients would benefit from intraoperative and postoperative cpidural anaesthesia and analgesia. ${ }^{3}$ Historically, however, this group of patients has not received these benefits because of the risks inherent in positioning for percutaneous placement of an epidural catheter. We report a case of a surgically placed epidural catheter for perioperative pain management in a patient with severe spinal trauma.

\section{Case report}

A 15-yr-old, 68-kg adolescent woman was admitted to hospital following a single motor yehicle rollover at highway speed. It took one hour to extricate her from the vehicle at which time she was found severely flexed at the waist. There was no loss of consciousness at the scene. She was haemodynamically stable throughout transfer and emergency evaluation. Past medical history consisted of hypothyroidism which was treated with $100 \mu \mathrm{g}$ synthyroid po daily. Physical examination revealed paraplegia consisting of a complete motor deficit with incomplete sensory sparing below $T_{12}$. Computerised tomographic images showed a burst fracture of $\mathrm{L}_{1}$ with retropulsion of bone fragments and $70 \%$ compromise of the central canal.

Surgery was scheduled to decompress the spinal canal and to help correct her kyphotic deformity. Before surgery, her pain had been managed with morphine patient-controlled-analgesia (PCA) with moderate success. Initial PCA settings were: dose $1.3 \mathrm{mg}$, six minute lockout, four hour limit $25 \mathrm{mg}$, and no basal infusion. This resulted in a visual analogue scale (VAS) pain scorc (0-10) of 2 to 7 (at rest) with an average score of 6 . The average VAS pain score (at rest) was decreased to 4 by increasing the morphine dose to $1.5 \mathrm{mg}$ (Figure 2).

On the day of operation, the patient was log-rolled onto the operating table. The unstable thoracolumbar spinal trauma prohibited positioning for preoperative epidural catheter placement. Gencral anaesthesia was induced with $2.5 \mu \mathrm{g} \cdot \mathrm{kg}^{-1}$ fentanyl and $4.0 \mathrm{mg} \cdot \mathrm{kg}^{-1}$ thiopentone followed by $0.7 \mathrm{mg} \cdot \mathrm{kg}^{-1}$ rocuronium. A \#37 left double lumen tube was placed and its position was confirmed by auscultation and fibreoptic bronchoscope. Arterial and central venous access were obtained. Anaesthesia was maintained with air, oxygen, isoflurane $\left(\mathrm{ET}_{\mathrm{ISO}}\right.$ 0.8-1.3), $200 \mu \mathrm{g}$ fentanyl, and
$150 \mathrm{mg}$ rocuronium. A cell saver was used for the seven hour operation.

A left thoracoabdominal approach for resection of the compressed $\mathrm{L}_{1}$ vertebra was undertaken. Spinal decompression was effected and vertebral reconstruction was performed using iliac crest bone graft and a titanium Z-plate. Prior to closure, a multi-orifice epidural catheter (Smiths Industries Medical Systems, Keene, $\mathrm{NH}$, USA) was placed by the surgeon under direct vision along the anterior epidural space above the vertebrectomy defect (Figure 1). It was inserted to a distance of $5 \mathrm{~cm}$. The catheter was then tunnelled out through the psoas muscle exiting through a separate stab incision using a 17-gauge Tuohy needle. The catheter was secured with a suture, sterile OpSite ${ }^{T M}$ (Smith \& Nephew Inc, Lachine, Quebec), and adhesive dressing. The catheter was tested with $3 \mathrm{ml}$ lidocaine $1.5 \%$ with epinephrine. This was followed with $5 \mathrm{ml}$ bupivacaine $0.25 \%$. Subsequently, an infusion of $5 \mu \mathrm{g} \cdot \mathrm{ml}^{-1}$ fentanyl and bupivacaine $0.10 \%$ was started at $8 \mathrm{ml}^{-1} \mathrm{hr}^{-1}$ using patient controlled epidural analgesia (PCEA). Initial PCEA settings were: bolus $5 \mathrm{ml}$, lockout $10 \mathrm{~min}$, four

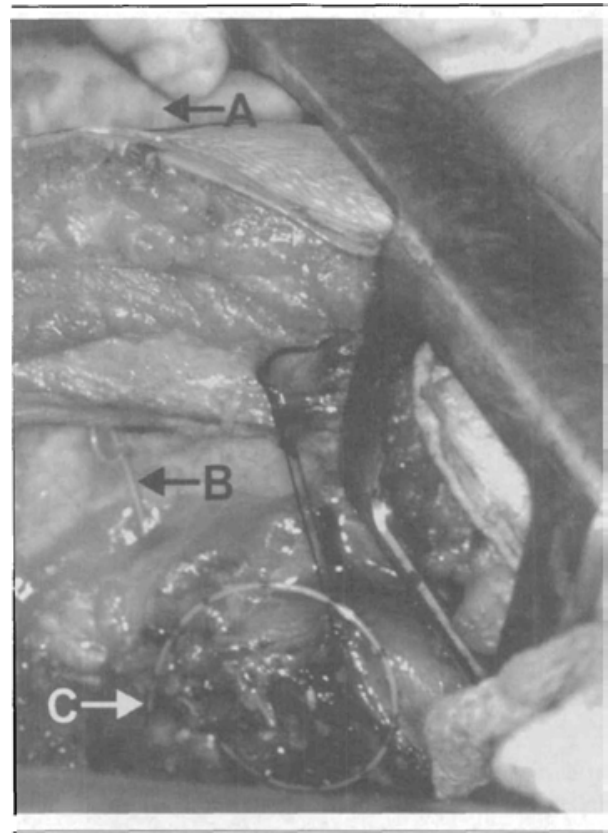

FIGURE 1 Course of surgically placed epidural catheter

$A$ - exit poine through skin, $B$ - entry point into chest wall, and $C$ - insertion point into epidural space. 


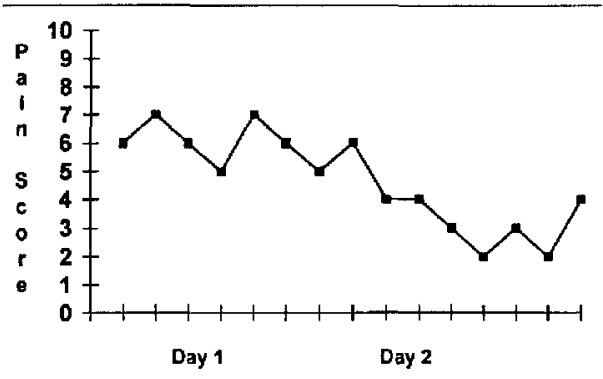

FIGURE 2 Pre-operative VAS Pain Scores while receiving PCA. The PCA morphine dose was increased on Day 2.

hour maximum $80 \mathrm{ml}$, with a baseline infusion of $8 \mathrm{ml} \cdot \mathrm{hr}^{-1}$. This could be increased by $2 \mathrm{ml} \cdot \mathrm{hr}^{-1}$ to a maximum of $14 \mathrm{ml} \cdot \mathrm{hr}^{-1}$. The patient received standard postoperative monitoring on the Acute Pain Service at our institution consisting of: block level, sedation scores, VAS pain scores (at rest), respiratory rate, heart rate, blood pressure and temperature. Initial postoperative arterial blood gas analysis revealed: $\mathrm{pH} 7.34, \mathrm{PaCO}_{2}$ $43 \mathrm{mmHg}, \mathrm{PaO}_{2} 214 \mathrm{mmHg}, \mathrm{HCO}_{3}-23 \mathrm{mmol} \cdot \mathrm{L}^{-1}$, base excess $-2, \mathrm{O}_{2}$ saturation $99 \%$, and a haemoglobin concentration of $9.7 \mathrm{~g} \cdot \mathrm{dl}^{-1}$ while breathing $3 \mathrm{~L} \cdot \mathrm{min}^{-1} \mathrm{O}_{2}$ via nasal canula.

Postoperatively, the patient's pain control was excellent. A $\mathrm{T}_{6}$ bilateral sensory block was achieved with $8 \mathrm{ml} \cdot \mathrm{hr}^{-1}$. This provided VAS pain scores (at rest) of $0-2$ (average of 1 ) in spite of a large thoracotomy incision (Figure 3). The respiratory rate was 14-18 hair after being fitted with a thoracolumbar spinal orthosis. She had an uncomplicated postoperative course and was referred to Rehabilitation Medicine for further therapy.

\section{Discussion}

We have described successful perioperative analgesia using a surgically placed epidural catheter in a patient with spinal trauma. While epidural analgesia, with surgically placed catheters, is being used for major spine reconstructive surgery, there are no reported cases of such a technique having been used in patients with spinal cord injuries in the North American literature.

Epidural anaesthesia and analgesia have beneficial effects in the perioperative period. ${ }^{3}$ In addition to pain relief, epidural anaesthesia affects most organ systems. Specifically, improved pulmonary function, 4,5 decreased postoperative diaphragmatic dysfunction, ${ }^{6}$ improved chest wall mechanics, ${ }^{7}$ lower incidences of arterial and

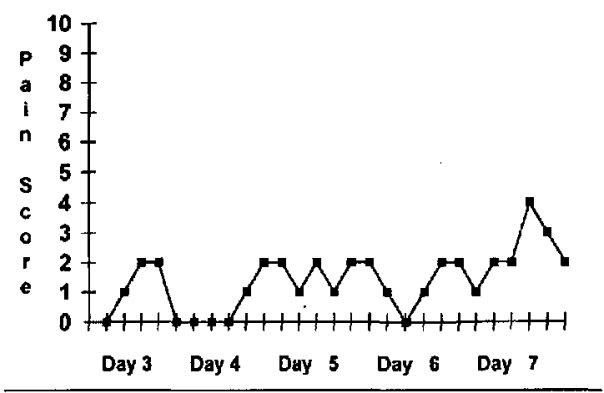

FIGURE 3 Post-operative VAS Pain Scores while receiving PCEA which was discontinued on Day 7 and the patient was changed to oral analgesics.

venous thromboses, ${ }^{8}$ shortened postoperative ileus, attenuated stress response, ${ }^{10,11}$ decreased immunosuppression, ${ }^{12}$ as well as improvements in myocardial oxygen supply and demand in patients with coronary artery disease $^{13-15}$ have been reported.

There are potential disadvantages associated with both the placement of the catheter and administration of drugs via this route. Placement carries the risks of dural puncture, ${ }^{16}$ paraesthesias, neurological injury, ${ }^{16}$ and paraplegia. ${ }^{17}$ Epidural local anaesthetics can lead to: high spinal anaesthesia from inadvertent intrathecal administration, ${ }^{18}$ cardiovascular collapse from intravascular injection, ${ }^{19}$ and excessive motor or autonomic blockade resulting in hypotension, urinary retention, weakness, and pressure necrosis. ${ }^{20}$ Epidural opioids are associated with respiratory depression, pruritus, nausea, and urinary retention. ${ }^{21}$

Surgically placed epidural catheters have the ability to provide the above advantages, while avoiding many of the potential complications. The principle advantage comes from avoidance of complications associated with their insertion. Patients requiring spinal precautions cannot be positioned for regional anaesthesia but, with this technique, concern over patient positioning is eliminated. The catheters are placed under direct vision in the correct anatomical position. Insertion to the desired depth is performed knowing the exact relationship to the last port of the multi-orifice catheter. Dural trauma, with its associated problems of post dural puncture headache and potential subarachnoid block, should be eliminated. While the incidence of neurological insult as a result of percutaneous epidural catheter insertion is very rare, ${ }^{16}$ surgical placement under direct vision should prevent this complication. Paraplegia secondary to epidural haematoma can also be expected to become even more rare than presently reported. ${ }^{16,17}$ 
The use of regional anaesthesia in the presence of a fresh spinal cord injury and neurological deficit is controversial. We recognise that the use of regional anaesthesia and analgesia may potentially mask a new postoperative neurological deficit. However, we believe that the probability of missing a new postoperative deficit is very small with this technique. First, the incidence of a new deficit postoperatively is unknown, but rare. Second, we use low concentrations of local anaesthetic (bupivacaine 0.05-0.10\%) combined with $5 \mu \mathrm{g} \cdot \mathrm{ml}^{-1}$ fentanyl which allows for assessment of gross motor and sensory function. This is analogous to the use of low dose "walking epidurals" for labour analgesia. The neurosurgeons in our institution do not believe that this low dose technique impairs their clinical management of these patients. Lastly, if there is any evidence of a new neurological deficit, the patient would go directly to Magnetic Resonance Imaging to delineate any pathology present.

Surgical positioning of epidural catheters into an open epidural space raises new considerations. The action and spread of local anaesthetic in the epidural space may be altered. A damaged, oedematous spinal cord is unlikely to respond normally to local anaesthetics and may be resistant to their effect. Drug may egress from the inferior border of the epidural space toward the surgical site. This might create a potentially larger volume of distribution for the drugs and may result in a less dense block requiring higher concentrations or larger volumes of drug to effect the same degree of blockade. Systemic toxicity might arise as a result of increased vascular uptake in a fresh postoperative surgical field. However, the epidural space is already a highly vascular area and, with adequate surgical haemostasis, this is unlikely. Although epidural abscesses are very rare, they can have devastating sequelae. ${ }^{22,23}$ The risk of infection should not be substantially increased with this technique. ${ }^{24}$ This is a clean, uncontaminated surgical field through which the catheter passes only transiently. Most epidural abscesses occur as a result of haematogenous spread and are not related to catheter placement. ${ }^{23}$ Catheter removal is unlikely to be more difficult or to disrupt the surgical wound when the catheter is tunnelled through its own site some distance from the surgical incision. In the absence of surgically induced dural trauma, catheter migration into the subarachnoid space should not be of concern. However, in the presence of post-traumatic dural tears, this technique may be contra-indicated. Intravascular catheter migration is still a potential complication, but is not expected to occur with greater frequency than with percutaneous epidural placement. Catheter dislodgment is also a potential concern. The catheter maybe more prone to migrate away from midline in postoperative tissues compared to a catheter placed into normal tissue planes. To our knowledge, there is no evidence to support or negate such speculation.

In summary, we report the successful perioperative anaesthetic and analgesic management of a surgically placed epidural catheter in a patient with an unstable thoracolumbar spine. We believe that the many potential benefits of such a technique outweigh the exceedingly rare potential complications or costs. Further prospective research into the effectiveness of this means of perioperative anaesthesia and analgesia is warranted.

\section{References}

1 MatKenize CF, Shin B, Krishnaprasad D, McCormack F, Illingworth $W$. Assessment of cardiac and respiratory function during surgery on patients with acutc quadriplegia. J Neurosurg 1985; 62: 843-9.

2 Keblet $H$. Surgical stress: the role of pain and analgesia. Br J Anaesth 1989; 63; 189-95.

3 Liu S, Carpenter RL, Neal JM. Epidural anesthesia and analgesia. Their role in postoperative outcome. Anesthesiology 1995; 82: 1474-506.

4 McCarthy GS. The effect of thoracic extradural analgesia on pulmonary gas distribution, functional residual capacity and airway closure. $\mathrm{Br}$ J Anaesth 1976; $48: 243-7$.

5 Guinard J-P, Maprocordatos $P_{2}$ Chiolero $R$, Carpenter $R L$. A randomized comparison of intravenous persus lumbar and thoracic epidural fentanyl for analgesia after thoracotomy. Anesthesiology 1992; 77: 1108-15.

6 Pansard J-L, Mankikian B, Bertrand $M$, Kieffer $E$, Clergue $F$, Viars $P$. Effects of thoracic extradural block on diaphragmatic electrical activity and contractility after upper abdominal surgery. Anesthesiology 1993; 78: 63-71.

7 Fratacci $M-D$, Kimball WR, Wain JC, Kacmarek RM, Polaner DM, Zapol WW. Diaphragmatic shortening after thoracic surgery in humans. Anesthesiology 1993; $79 ; 654-65$.

8 Sorenson RM, Pace NL. Anesthetic techniques during surgical repair of femoral neck fractures. A meta-analysis. Anesthesiology 1992; 77: 1095-104.

9 Udassin R, Eimeri D, Sehiffman J, Haskel r. Epidural anesthesia accelerates the recovery of postischemic bowel motility in the rat. Anesthesiology 1994; 80: 832-6.

10 Yeager MP, Glass DD, Neff RK, Brinck-Johnson T. Epidural anesthesia and analgesia in high-risk surgical patients. Aresthesiology 1987; 66: 729-36. 
11 Christensen P, Brandt MR, Rem J, Keblet $H$. Influence of extradural morphine on the adrenocortical and hyperglycaemic response to surgery. $\mathrm{Br} \mathrm{J}$ Anaesth 1982; 54: 23-6.

12 Tonnesen $E$, Wahlgreen $G$. Influence of extradural and general anaesthesia on natural killer cell activity and lymphocyte subpopulations in patients undergoing hysterectomy. Br J Anaesth 1988; 60: 500-7.

13 Blomberg $S$, Emanwelsson $H$, Kvist $H$, et al. Effects of thoracic epidural anesthesia on coronary arteries and arterioles in patients with coronary artery disease. Anesthesiology 1990; 73: 840-7.

14 Davis RF, DeBoer LWV, Maroko PR. Thoracic epidural anesthesia reduces myocardial infarct size after coronary artery occlusion in dogs. Anesth Analg 1986; 65: $711-7$.

15 Klassen GA, Bramwell RS, Bromage PR, ZboromskaShis $D T$. Effect of acute sympathectomy by epidural anesthesia on the canine coronary circulation. Anesthesiology 1980; 52: 8-15.

16 Kane RE. Neurologic deficits following epidural or spinal anesthesia. Anesth Analg 1981; 60: 150-61.

17 Sage DJ. Epidurals, spinals, and bleeding disorders in pregnancy: a review. Anaesth Intensive Care 1990; 18: 319-26.

18 Kim YI, Mazza NM, Marx GF. Massive spinal block with hemicranial palsy after a "test dose" for extradural analgesia. Anesthesiology 1975; 43: 370-1.

19 Albright GA. Cardiac arrest following regional ancsthesia with etidocaine and bupivacaine (Editorial). Anesthesiology 1979; 51: 385-7.

20 Cohen $S$, Amar D, Pantuck CB, Pantuck EJ, Weissman $A B$. Adverse effects of cpidural $0.03 \%$ bupivacaine during analgesia after cesarean section. Anesth Analg 1992; 75: 753-6.

21 Cousins MJ, Mather LE. Intrathecal and epidural administration of opioids. Anesthesiology 1984; 61: 276-310.

22 Danner RL, Hartwan BJ. Update of spinal epidural abscess: 35 cases and review of the literature. Reviews of Infectious Disease 1987; 9: 265-74.

23 Wedel DJ, Horlocker TT. Risks of regional anesthesia infectious, septic. Reg Anesth 1996; 21: 57-61.

24 Hunt JR, Rigor BM SF, Collins JR. The potential for contamination of continuous epidural catheters. Anesth Analg 1977; 56: 222-4. 